\title{
Obesity epidemic has emerged among Nigerians
}

\author{
Sally N Akarolo-Anthony ${ }^{1,2^{*}}$, Walter C Willett ${ }^{1,3}$, Donna Spiegelman ${ }^{3,4}$ and Clement A Adebamowo ${ }^{1,2,5}$
}

\begin{abstract}
Background: Data from the WHO shows that the prevalence of overweight and obesity increased by 20\% between 2002 and 2010 in Nigeria. We conducted this study to examine the correlates of this fast growing epidemic.
\end{abstract}

Methods: We conducted a cross-sectional study among a random sample of 1058 adults, who were visitors and staff of a government worksite in Abuja, an urban city in Nigeria. The study participants had varying socio-economic status and a wide range of occupations, including skilled labor and professionals. Log-binomial regression models were used to estimate the multivariable-adjusted associations of potential determinants with the prevalence of overweight and obesity.

Result: The mean age and body-mass index of the study population were 42 years \pm (9.3) and $27 \mathrm{~kg} / \mathrm{m}^{2} \pm(4.8)$. The overall prevalence of overweight or obesity (body-mass index $\geq 25 \mathrm{~kg} / \mathrm{m}^{2}$ ) was $64 \%(74 \%$ of the women and $57 \%$ of the men). For women compared to men, the prevalence ratio (PR) and (95\% confidence interval, Cl) was 1.24 (95\% Cl $1.08,1.43, \mathrm{p}=0.004)$, for overweight, and $2.54(95 \% \mathrm{Cl} 2.08,3.10, \mathrm{p}=<0.0001)$, for obesity. Individuals aged 40 - 49 years were more likely to be overweight or obese. The PR for overweight and obesity was 1.45 ( $95 \%$ Cl 1.07, 1.97), p for age trend $=0.002$ and $8.07(95 \% \mathrm{Cl} 3.01,21.66, \mathrm{p}$ for age trend $=<0.0001)$ for those aged $40-49$ years, compared with those aged $<30$ years. Compared with the individuals in the lower socio-economic status, the PR for obesity among those in the middle and high socio-economic statuses, were $1.39(95 \% \mathrm{Cl} 1.13,1.72)$ and $1.24(95 \% \mathrm{Cl} 0.97,1.59)$ respectively, $p$ for trend $=0.003$.

Conclusion: About two-thirds of urban, professional, high socio-economic status Nigerian adults are either overweight or obese. The prevalence of overweight and obesity among this population of adult Nigerians, is as high as it is in the United Kingdom. Female gender and older age were independent predictors of overweight and obesity; while middle or high socio-economic status were independently associated with obesity.

Keywords: Overweight, Obesity, Nigeria

\section{Background}

Overweight and obesity, defined by the WHO as bodymass index $\geq 25 \mathrm{~kg} / \mathrm{m}^{2}$ and $\geq 30 \mathrm{~kg} / \mathrm{m}^{2}$, respectively, are associated with several diseases including cardiovascular disease, diabetes and several types of cancer cancer and cardiovascular disease [1]. In 2008, 1.4 billion adults aged 20 years and above were overweight or obese, of whom approximately 200 million men and 300 million women were estimated to be obese [2]. Although it had been projected that by 2030 , there will be 2.16 billion overweight

\footnotetext{
* Correspondence: sna094@mail.harvard.edu

'Department of Nutrition, Harvard School of Public Health, Boston, MA 02115, USA

${ }^{2}$ Office of Strategic Information and Research, Institute of Human Virology,

Abuja, Nigeria

Full list of author information is available at the end of the article
}

and 1.12 billion obese individuals globally [3], results from trend analysis suggest that 2 or more billion people worldwide are currently overweight or obese [4]. High blood pressure and high fasting plasma glucose were leading risk factors for disease worldwide in 2010 [1] and are in part caused by obesity. The global disease burden attributable to high body-mass index increased from 52 million in 1990 to 94 million disability-adjusted life-years in 2010 [1].

Although more people in developing countries now die from obesity-associated diseases, including ischemic heart disease, diabetes mellitus and cancer [5], many people are still under the impression that overweight and obesity affects only the Western world and that lower resource countries continue to struggle with only underweight, malnutrition and infections. This may not 
be the case because the obesity epidemic is growing faster in developing countries than in the developed world [6]. Among people aged 15 years and above, the WHO estimated that the prevalence of overweight and obesity in 2010 was as high as $63.8 \%$ and $21.3 \%$ respectively, for men, and $73.8 \%$ and $43.2 \%$ respectively, for women, in some Sub-Saharan Africa countries. Eritrea, Ethiopia, Democratic Republic of the Congo and Central African Republic had the lowest prevalence, while Seychelles, Lesotho, South Africa and Mauritius had the highest prevalence of overweight and obesity in Sub-Saharan Africa [7]. In general, the countries with lower prevalence of overweight and obesity tend to be those with low gross domestic product per capita and vice versa, suggesting that socio-economic status may be a determinant of overweight and obesity in some African countries.

According to the 2010 WHO survey data on Nigeria, the prevalence of overweight was $26 \%$ and $37 \%$ in men and women respectively, while the prevalence of obesity was $3 \%$ and $8.1 \%$ in men and women respectively [7]. Data from the WHO Global InfoBase, based on individuals aged 30 years and above, shows that the prevalence of overweight and obesity together increased by $23 \%$ in men and $18 \%$ in women, while the prevalence of obesity alone increased by $47 \%$ in men and $39 \%$ in women, between 2002 and 2010, in Nigeria [7].

Previous studies have shown that several factors including age, gender, marital and socio-economic statuses, occupation, urban residence, dietary intake and physical activity are associated with overweight and obesity [8-12]. Even though the prevalence of overweight and obesity in Nigeria continues to increase, there are few studies of its correlates. We therefore conducted this study to examine the prevalence of overweight and obesity and its potential correlates in an urban Nigerian population.

\section{Methods}

\section{Study population}

Between April 2010 and February 2011, we conducted a cross-sectional study among a random sample of 1058 workers and visitors at the Federal Secretariat Complex, a government worksite in Abuja, Nigeria, which houses the offices of federal public sector workers in central Nigeria. Because it is a federal establishment, the staff distribution is representative of Nigeria's ethnic and cultural diversity. We approached individuals aged over 18 years who reside within Abuja city to participate in the study; they had a wide range of occupations including skilled labor and professionals.

\section{Demographic, socio-economic factors and physical activity}

To verify that we had sampled a diverse population, we collected data on ethnicity, religion, level of education, and profession. To evaluate socio-economic status, we asked about household possessions including fan, refrigerator, television, bicycle, motorcycle, car, source of drinking water, type of sanitation, type of residence, home ownership, separate room for cooking, source of cooking fuel, respondent self-reported social class and interviewer-perceived social class. To assess physical activity levels, we asked about amount of time spent on different exercises/week, as defined in the WHO global physical activity recommendations for individuals aged $18-64$ years [13].

\section{Anthropometric measurements}

Trained research nurses measured individual height with a rigid tape measure, in accordance to the World Health Organization (WHO) multinational monitoring of trends and determinants in cardiovascular disease criteria [14]. To measure height, the participants' were asked to take off his/her shoes, hats or head ties; stand with back to the tape measure; and hold their head in a position where he/she can look straight at a spot, head high, on the opposite wall. A flat rule was placed on the participant's head, so that the hair (if present) was pressed flat. Height was measured to the nearest centimeter, at the level where the flat rule touched the rigid tape.

To measure weight, participants' were asked to remove heavy outer garments, empty their pockets and step on a weighing scale, which was placed on a hard, even surface. Weight was estimated using the Omron body sensor (Omron HBF-510 W Full Body Sensor Body Composition Monitor Scale). Body-mass index was estimated as a ratio of an individual's weight $(\mathrm{kg}) /$ height $\left(\mathrm{m}^{2}\right)$. Body-mass index categories were defined using the WHO cut points in units of $\mathrm{kg} / \mathrm{m}^{2}$, normal weight $=18.5-<25$, overweight $=25-<30$ and obese $\geq 30$.

\section{Dietary measurements}

The method of estimating calorie intake has been described elsewhere [15]. Briefly, dietary carbohydrate intake over the previous 1 year was estimated, with a modified semi-quantitative food frequency questionnaire. The food frequency questionnaire collected information on 11 main foods and 7 beverages. Participants were asked to report types of foods and beverages consumed; the frequency of consumption (number of times consumed daily, weekly and monthly); and the quantity consumed. We used the Nigerian food composition database [16] to translate dietary intake to calorie intake.

\section{Statistical analysis}

A total of 1058 participants were enrolled in this study. We excluded 17 persons who were underweight, defined as having a body-mass index $<18.5 \mathrm{~kg} / \mathrm{m}^{2}$. We generated a wealth index using the factor analysis (principal components) 
Table 1 Characteristics of the study population by body-mass index categories

\begin{tabular}{|c|c|c|c|c|c|c|c|c|c|}
\hline \multirow{2}{*}{ Characteristics } & \multirow[t]{2}{*}{ Overall \% } & \multicolumn{3}{|c|}{ Body-mass index categories $\left(\mathrm{kg} / \mathrm{m}^{2}\right)$} & \multirow{2}{*}{$\begin{array}{l}\text { Mean calories from } \\
\text { carbohydrates }\end{array}$} & & \multirow[t]{3}{*}{$985.7 \pm 502.7$} & \multirow[t]{3}{*}{$973.4 \pm 497.8$} & \multirow[t]{3}{*}{$862.8 \pm 482.4$} \\
\hline & & $18.5<25$ & $25-<30$ & $\geq 30.0$ & & & & & \\
\hline & & $n=377$ & $n=399$ & $n=265$ & Physical activity, \% & & & & \\
\hline \multirow{2}{*}{$\begin{array}{l}\text { Body-mass index } \\
\left(\mathrm{kg} / \mathrm{m}^{2}\right)\end{array}$} & & $22.5 \pm 1.6$ & $27.2 \pm 1.4$ & $33.8 \pm 3.2$ & - Low & 61 & 59 & 61 & 65 \\
\hline & & & & & - Moderate & 22 & 23 & 23 & 20 \\
\hline Age (years) & & $39.2 \pm 10.3$ & $42.6 \pm 9.0$ & $43.3 \pm 7.1$ & - High & 16 & 18 & 16 & 15 \\
\hline $\begin{array}{l}\text { Age categories } \\
\text { (years), \% }\end{array}$ & & & & & $\begin{array}{l}\text { Television } \\
\text { (hours/week), \% }\end{array}$ & & & & \\
\hline$-<30$ & 11 & 19 & 10 & 2 & - <6/week & 45 & 46 & 44 & 46 \\
\hline$-30-39$ & 28 & 31 & 22 & 32 & - 6 - 10/week & 28 & 29 & 28 & 26 \\
\hline$-40-49$ & 40 & 32 & 46 & 43 & - 11 - 20/week & 17 & 15 & 19 & 18 \\
\hline$-\geq 50$ & 21 & 18 & 22 & 23 & - > 20/week & 10 & 10 & 9 & 10 \\
\hline
\end{tabular}

- Male

- Female

Religion, \%

- Christianity

- Islam

Marital Status, \%

- Married

- Not married

Education, \%

- None

- Primary (Elementary

school)

- Secondary

(High school)

- $\geq$ Tertiary (College)

Occupation, \%

- Self-employed

- Unskilled manual

- Skilled manual

- Professional/ executive

Socio-economic status, \%

- Low

- Middle

- High

Sugar sweetened

beverages, $\%$

$-<1 /$ month

$-\leq 1 /$ week

- 2 - 6/week

- $\geq 1 /$ day
71

29

67

33

34

66

82

18

22

80

20

82

18

0

0

15

85

77

3

7

40

50

40

40

20

17

45

27

11
Table 1 Characteristics of the study population by body-mass index categories (Continued)

procedure and varimax rotation as previously described by Filmer and Pritchett [17], to compute socio-economic status.

We used mean and standard deviation (SD) for continuous variables while $t$-tests were used to assess the significance of differences between groups in the distribution of continuous variables; $\chi^{2}$ tests were used for categorical variables; Spearman and Pearson correlation coefficients were used to assess the correlation between the covariates.

Univariate and multivariate analyses with log-binomial regression models were conducted to examine the associations between potential correlates and the prevalence of overweight and obesity [18-20]. All variables that were associated with overweight and obesity in the univariate analyses with $\mathrm{p}$-value $\leq 0.2$, were included in the multivariate model [21]. Stepwise restricted cubic splines were non-linearity used the likelihood ratio test, comparing the model with only the linear term to the model with the linear and the cubic spline terms [23]. The fit of the models were assessed with Akaike information criterion. All analyses were conducted with SAS for UNIX statistical software (version 9.2; SAS Institute).

\section{Ethics}

The study was conducted according to the Nigerian National Code for Health Research Ethics and the Declaration of Helsinki. Ethical approval to conduct this study was obtained from the Institute of Human Virology Nigeria Health Research Ethics Committee. Individuals were informed about the study and were requested to consent before participating in the study.

\section{Result}

The mean age (SD) of the participants was 41.6 (9.3) years; $40 \%$ (416/1041) were women and 60\% (625/1041) were men. The mean (SD) body-mass index of all the used to assess and graph non-linearity [22]. Tests for 
Table 2 Prevalence of overweight and obesity among urbanized adult Nigerians, by gender

\begin{tabular}{cccc}
\hline $\begin{array}{c}\text { Body-mass index } \\
\text { category }\end{array}$ & $\begin{array}{c}\text { Body-mass index } \\
\text { cut-off point }\end{array}$ & Women (\%) & Men (\%) \\
\hline Normal weight & $18.50-24.99$ & 26 & 43 \\
Overweight & $25.00-29.99$ & 32 & 42 \\
Obese & $\geq 30.00$ & 42 & 15 \\
\hline
\end{tabular}

participants was $27.2(4.8) \mathrm{kg} / \mathrm{m}^{2} ; 36 \%(377 / 1041)$ of the study participants were of normal weight 38\% (399/1041) were overweight and $26 \%(265 / 1041)$ were obese. The mean (SD) body-mass index was $22.5(1.6) \mathrm{kg} / \mathrm{m}^{2}$ for the participants within the normal weight range, $27.2(1.4) \mathrm{kg} / \mathrm{m}^{2}$ among the overweight and $33.8(3.2) \mathrm{kg} / \mathrm{m}^{2}$ for those who were obese. Table 1 shows the demographic characteristics of the study population overall and by body-mass index categories. Some $32 \%(134 / 416)$ of the women and $42 \%(265 / 625)$ of the men were overweight, while $42 \%$ $(174 / 416)$ of the women and $15 \%(94 / 625)$ of the men were obese. Table 2 shows the prevalence of overweight and obesity by gender.

Individuals who were older than 30 years were more likely to be overweight or obese than younger persons. Compared to individuals aged $<30$ years, the prevalence ratio (PR) for being overweight was $1.45(95 \% \mathrm{CI}=1.07$, 1.97) for individuals aged $40-49$ years and 1.35 (95\% $\mathrm{CI}=0.98,1.85$, $\mathrm{p}$-value for trend test $=0.002$ ) for individuals aged 50 years and above; while the PR for obesity was $8.07(95 \% \mathrm{CI}=3.01,21.66)$ for individuals aged $40-$ 49 years and $7.74(95 \% \mathrm{CI}=2.88,20.81 \mathrm{p}$-value for trend test $=<0.0001)$ in individuals who are 50 years of age and above. The prevalence of overweight and obesity was related to age in a non-linear manner $(\mathrm{p}<0.001)$. Both conditions increased linearly with age up to around age 45, at which point the prevalence of these conditions remained constant or even declined (Figure 1). Comparing women to men, the PR and 95\% CI for overweight and obesity were $1.24(95 \% \mathrm{CI}=1.08,1.43 \mathrm{p}=0.004)$ and 2.54 $(95 \% \mathrm{CI}=2.08,3.10 \mathrm{p}=<0.0001$, respectively. Being married was also associated with increased prevalence of overweight and obesity. Table 3 shows the results of univariate and multivariate analyses of the risk factors for the prevalence of overweight while Table 4 shows the same information for obesity.

Higher occupational level and a higher socio-economic status were significantly associated with an increased prevalence of obesity but not overweight. The PR for obesity among those in the middle and high socioeconomic categories, were 1.39 (95\% CI 1.13, 1.72) and $1.24(95 \%$ CI $0.97,1.59)$ respectively, $\mathrm{p}$ for trend $=$ 0.003 , compared with the lower socio-economic status category

\section{Discussion}

Only $36 \%$ of the participants in this study had normal body-mass index, the remaining $64 \%$ were either overweight or obese. Factors that were significantly associated with higher prevalence of overweight and obesity were being in older age groups, and female gender. In addition, having a more professional job and belonging to middle or high socio-economic status were significantly associated with increased obesity prevalence.

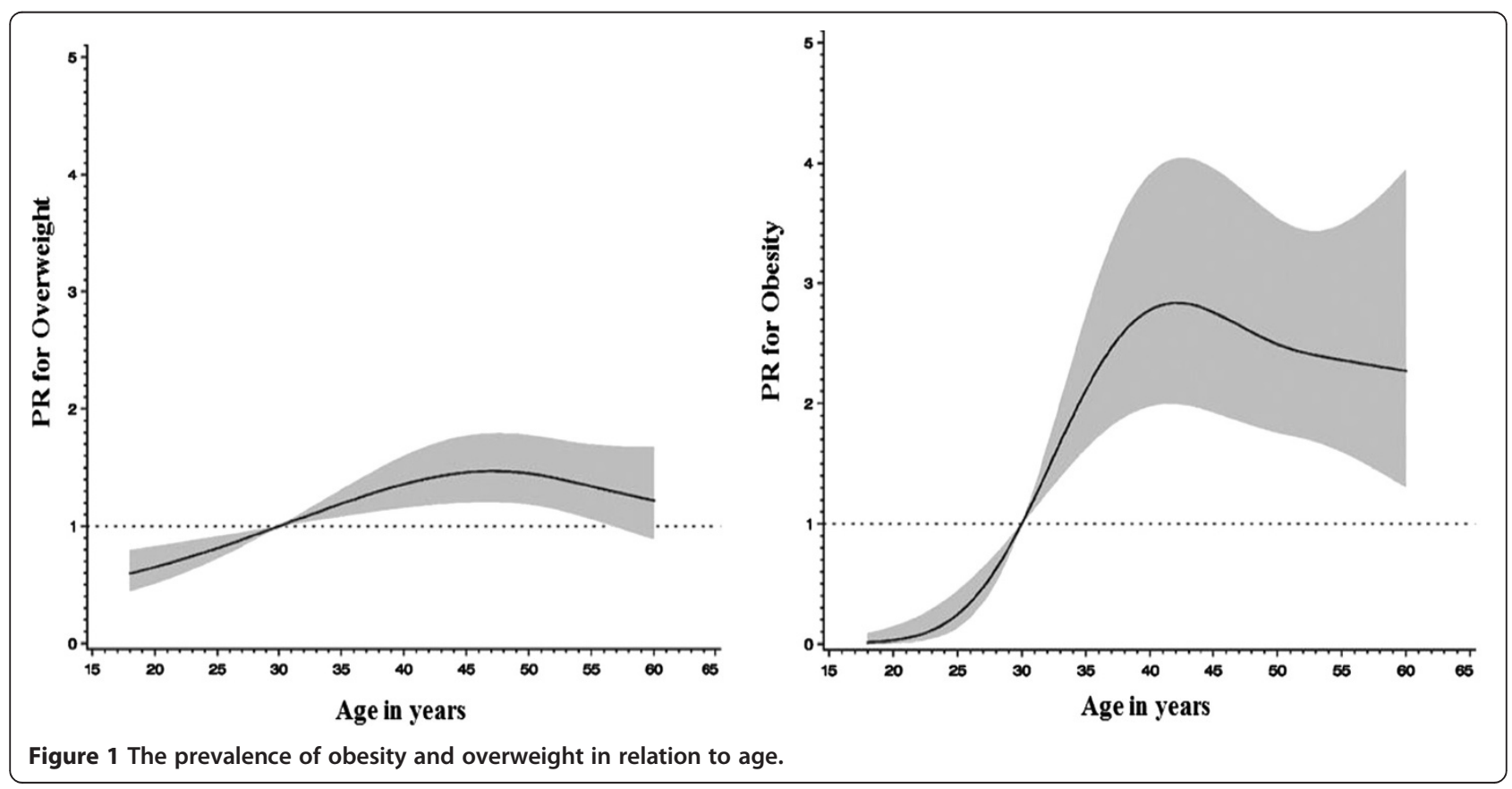


Table 3 Univariate and multivariate analyses of risk factors for overweight vs. normal weight

\begin{tabular}{|c|c|c|c|c|c|}
\hline \multirow[t]{2}{*}{ Characteristics } & \multirow[t]{2}{*}{$\mathrm{N}$} & \multicolumn{2}{|l|}{ Univariate } & Multivariate & \multirow[t]{2}{*}{ p-value } \\
\hline & & RR $(95 \% \mathrm{Cl})$ & p-value & RR $(95 \% \mathrm{Cl})$ & \\
\hline Age categories (years) & & & $<0.0001$ & & 0.002 \\
\hline$-<30$ & 113 & 1.00 & & 1.00 & \\
\hline$-30-39$ & 206 & $1.23(0.92,1.66)$ & & $1.11(0.81,1.52)$ & \\
\hline$-40-49$ & 301 & $1.71(1.31,2.23)$ & & $1.45(1.07,1.97)$ & \\
\hline$-\geq 50$ & 156 & $1.58(1.18,2.10)$ & & $1.35(0.98,1.85)$ & \\
\hline Sex & & & 0.17 & & 0.004 \\
\hline - Male & 533 & 1.00 & & 1.00 & \\
\hline - Female & 241 & $1.11(0.96,1.27)$ & & $1.24(1.08,1.43)$ & \\
\hline Marital status & & & $<.0001$ & & 0.043 \\
\hline - Not married & 193 & 1.00 & & 1.00 & \\
\hline - Married & 583 & $1.43(1.18,1.73)$ & & $1.24(0.99,1.54)$ & \\
\hline Education & & & 0.02 & & 0.46 \\
\hline - Secondary (High school) & 186 & 1.00 & & & \\
\hline - $\geq$ Tertiary (College) & 582 & $1.32(1.09,1.59)$ & & $1.13(0.92,1.39)$ & \\
\hline - None/Primary (Elementary) & 8 & $1.59(0.61,3.47)$ & & $1.39(0.30,3.82)$ & \\
\hline Occupation & & & 0.007 & & 0.68 \\
\hline - Skilled manual & 323 & 1.00 & & & \\
\hline - Professional/executive & 364 & $1.14(0.99,1.32)$ & & $1.00(0.86,1.16)$ & \\
\hline - Unskilled manual & 65 & $0.71(0.51,1.01)$ & & $0.84(0.59,1.18)$ & \\
\hline - Self-employed & 24 & $0.84(0.52,1.37)$ & & $0.79(0.38,1.64)$ & \\
\hline Socio-economic status & & & 0.0007 & & 0.10 \\
\hline - Low & 342 & 1.00 & & 1.00 & \\
\hline - Middle & 280 & $1.34(1.14,1.56)$ & & $1.18(1.01,1.39)$ & \\
\hline - High & 154 & $1.26(1.04,1.52)$ & & $1.15(0.95,1.39)$ & \\
\hline Sugar sweetened beverages & & & 0.60 & & \\
\hline$-<1 /$ month & 126 & 1.00 & & & \\
\hline$-\leq 1 /$ week & 356 & $1.10(0.90,1.35)$ & & & \\
\hline-2 - 6/week & 210 & $1.07(0.86,1.34)$ & & & \\
\hline$-\geq 1 /$ day & 84 & $0.96(0.72,1.28)$ & & & \\
\hline Physical activity & & & 0.61 & & \\
\hline - Low & 466 & 1.00 & & & \\
\hline - Moderate & 180 & $0.97(0.82,1.15)$ & & & \\
\hline - High & 130 & $1.91(0.74,1.11)$ & & & \\
\hline Television (hours/week) & & & 0.49 & & \\
\hline - <6/week & 350 & 1.00 & & & \\
\hline - 6 - 10/week & 219 & $1.00(0.85,1.18)$ & & & \\
\hline - 11 - 20/week & 133 & $1.13(0.94,1.35)$ & & & \\
\hline - > 20/week & 74 & $0.94(0.72,1.22)$ & & & \\
\hline
\end{tabular}

Some $77 \%$ of our study participants had at least a college degree and $50 \%$ had professional jobs. Data from the 2008 Nigeria Demographic and Health Survey [24] shows that Abuja, federal capital territory, has the highest proportion of men and women who have completed a secondary school education, among all 36 states and the federal capital territory, in Nigeria. Our findings are consistent with studies on obesity in Sub Saharan Africa, that the prevalence of obesity was more marked among urban, highly educated women [8], who are more likely 
Table 4 Univariate and multivariate analysis of risk factors for obesity vs. normal weight

\begin{tabular}{|c|c|c|c|c|c|}
\hline Characteristics & $\mathrm{N}$ & $\begin{array}{l}\text { Univariate } \\
\mathrm{RR}(95 \% \mathrm{Cl})\end{array}$ & p-value & $\begin{array}{l}\text { Multivariate } \\
\text { RR }(95 \% \mathrm{Cl})\end{array}$ & p-value \\
\hline Age categories (years) & & & $<0.0001$ & & $<0.0001$ \\
\hline$-<30$ & 77 & 1.00 & & 1.00 & \\
\hline$-30-39$ & 201 & $8.14(3.09,21.43)$ & & $6.73(2.51,18.02)$ & \\
\hline$-40-49$ & 234 & $9.46(3.61,24.78)$ & & $8.07(3.01,21.66)$ & \\
\hline$-\geq 50$ & 130 & $9.03(3.42,23.87)$ & & $7.74(2.88,20.81)$ & \\
\hline Sex & & & $<.0001$ & & $<0.0001$ \\
\hline - Male & 358 & 1.00 & & 1.00 & \\
\hline - Female & 282 & $2.43(1.99,2.96)$ & & $2.54(2.08,3.10)$ & \\
\hline Marital status & & & 0.0001 & & 0.009 \\
\hline - Not married & 166 & 1.00 & & 1.00 & \\
\hline - Married & 476 & $1.58(1.22,2.04)$ & & $1.24(1.00,1.53)$ & \\
\hline Education & & & 0.0003 & & 0.83 \\
\hline - Secondary (High school) & 148 & 1.00 & & 1.00 & \\
\hline - $\geq$ Tertiary (College) & 489 & $1.74(1.31,2.31)$ & & $1.03(0.80,1.34)$ & \\
\hline - None/Primary (Elementary) & 4 & $1.80(0.26,7.33)$ & & $1.21(0.38,5.42)$ & \\
\hline Occupation & & & $<.0001$ & & 0.008 \\
\hline - Skilled manual & 259 & 1.00 & & 1.00 & \\
\hline - Professional/executive & 317 & $1.35(1.12,1.64)$ & & $1.25(1.06,1.48)$ & \\
\hline - Unskilled manual & 50 & $0.43(0.22,0.83)$ & & $0.69(0.36,1.31)$ & \\
\hline - Self-employed & 16 & $0.34(0.09,1.24)$ & & $0.47(0.13,1.65)$ & \\
\hline Socio-economic status & & & $<0.0001$ & & 0.003 \\
\hline - Low & 263 & 1.00 & & 1.00 & \\
\hline - Middle & 254 & $2.01(1.60,2.53)$ & & $1.39(1.13,1.72)$ & \\
\hline - High & 125 & $1.66(1.26,2.19)$ & & $1.24(0.97,1.59)$ & \\
\hline Sugar sweetened beverages & & & 0.93 & & \\
\hline$-<1 /$ month & 119 & 1.00 & & & \\
\hline$-\leq 1 /$ week & 272 & $0.86(0.67,1.10)$ & & & \\
\hline - 2 - 6/week & 173 & $0.92(0.70,1.19)$ & & & \\
\hline$-\geq 1 /$ day & 78 & $0.93(0.67,1.29)$ & & & \\
\hline Physical activity & & & 0.26 & & \\
\hline - Low & 393 & 1.00 & & & \\
\hline - Moderate & 142 & $0.87(0.68,1.10)$ & & & \\
\hline - High & 107 & $0.83(0.63,1.10)$ & & & \\
\hline Television (hours/week) & & & 0.65 & & \\
\hline - <6/week & 294 & 1.00 & & & \\
\hline - 6 - 10/week & 177 & $0.95(0.75,1.19)$ & & & \\
\hline - 11 - 20/week & 106 & $1.12(0.88,1.44)$ & & & \\
\hline - > 20/week & 65 & $0.97(0.70,1.35)$ & & & \\
\hline
\end{tabular}

to have sedentary lifestyles and access to processed foods, compared to women in rural areas.

The findings from our spline analysis showed that, the prevalence ratio of obesity increases rapidly after age 30 years and peaks at age $40-49$ years. Our findings, on the prevalence of overweight and obesity among adults aged 30 years or older in Nigeria, were higher than in the WHO 2010 survey [25]. However, unlike our study which was based on an urban population, the WHO survey included rural and urban populations. Our 
estimates were also substantially higher than estimates from other recent studies in Nigeria. Table 5 shows how the prevalence estimates obtained from these studies, compare to our prevalence estimates and the setting for each study population. In contrast to these studies, our study sample was urban, more educated and more likely to be engaged in professional vocations compared to average Nigerians [24]. As the Nigerian economy continues to improve, food availability and individuals' dietary calorie intake may have increased, thus contributing to more people becoming overweight and obese. People living in rural Nigeria still consume more traditional Nigerian diets which have more whole grains, have higher fiber and fewer calories. They may also have less sedentary lifestyles compared to those in the urban areas. However, there is scarce data, on the nutritional and physical activity patterns, among Nigerians.

Our results are consistent with other African studies, that overweight and obesity is more prevalent among women, persons older than 30 years and married individuals $[9,11,12,28,32]$. The gender disparity among overweight and obesity is not well understood. However, weight gain during and after pregnancy, the perception of weight gain as evidence of high socio-economic status [33], fattening practices among women [34,35] and increased prevalence of more sedentary occupations among Sub-Saharan African women, may contribute to this. Although women in Africa may do more household chores, men's professions and work related to engaging in these occupations, participation in sports and other physical activities, may contribute to the different prevalence between men and women [15]. In addition, Nigerian women in urban areas who are highly educated and have higher socio-economic status, may not engage in household chores as they are more likely to have maids who do the work.

Higher socio-economic status and occupational level were significantly associated with the risk of obesity. This finding was consistent with the pattern of results in low- and middle-income countries [10]. We noted that those that were at least moderately physically active were more likely to be overweight or obese, even though this was not statistically significant. Some of these people may include those trying to lose weight. Also, obesity and overweight was more prevalent among those reporting consumption of fewer carbohydrate calories. This may be due to underreporting of dietary intake by those who were overweight and obese [36,37]. People with higher dietary calorie intake are also likely to be more physically active. Unlike studies done in developed countries where hours spent watching TV is associated with obesity [38], we did not find this to be the case in this study population.

The prevalence of overweight and obesity in Abuja is high, compared to other cities in Nigeria $[9,26-30]$ but it is similar to the prevalence in developed countries like the United Kingdom, where a greater proportion of men than women (42\% compared with $32 \%$ ) were classified as overweight and $26 \%$ of the adults were classified as obese in 2010 [39]. This dramatically increasing prevalence is of particular concern, in view of increased risk of non-communicable diseases such as hypertension, diabetes and cancer. Our findings argue for public health interventions that seek to promote healthy diets and increase physical activity, among the rapidly urbanizing populations, particularly of the developing world.

Our study is limited by its cross-sectional design and its setting in an adult urban population, thus the results cannot be generalized to rural populations or children. As there were many different ethnic groups, we did not have sufficient power to address the role of these unique ethnicities on overweight or obesity. Also, dietary carbohydrate intake was assessed over the past year, which may not be the best representation of the participants' longterm intake. However, we made objective measurements of anthropometry, using standardized guidelines and techniques, and we found correlates of overweight and obesity in this Nigerian population, that were similar to other highly urban populations in West Africa $[9,11,12]$.

Table 5 Summary of recent prevalence studies on overweight and obesity among adult Nigerians

\begin{tabular}{|c|c|c|c|c|c|c|c|}
\hline Ref. & $\begin{array}{l}\text { Year(s) of data } \\
\text { collection }\end{array}$ & Location in Nigeria & $\begin{array}{l}\text { Sample } \\
\text { size }\end{array}$ & $\begin{array}{c}\text { Age } \\
\text { range }\end{array}$ & $\begin{array}{l}\text { Mean age } \\
\text { (SD) }\end{array}$ & $\begin{array}{l}\text { Overweight } \\
\text { (\%) }\end{array}$ & $\begin{array}{l}\text { Obesity } \\
(\%)\end{array}$ \\
\hline Present Study & $2010-2011$ & Abuja, Central, (Urban) & 1041 & $18-65$ & $41.6(9.3)$ & 38 & 26 \\
\hline [26] & $2010-2011$ & $\begin{array}{l}\text { Maiduguri, North-east, } \\
\text { (Urban) }\end{array}$ & 1818 & $20-65$ & $32.3(10)$ & 22.8 & 8.1 \\
\hline$[27]$ & - & Abia, South-east, (Semi-rural) & 1584 & $18-29$ & $21.8(2.1)$ & 20.7 & - \\
\hline [28] & & Lagos, South-west, (Urban) & 900 & $20-80$ & $37.8(14.3)$ & 29 & 9 \\
\hline [29] & $2008-2009$ & Imo, South-east, (Rural) & 2156 & $18-90$ & $42.6(11.3)$ & - & 6 \\
\hline$[30]$ & - & Benue, (Rural \& Urban) & 435 & $18-45$ & $24.2(0.2)$ & 22.1 & 3.9 \\
\hline$[31]$ & 2006 & Katsina, North-west, (Urban) & 300 & - & $37.6(10.6)$ & 53.21 & 21 \\
\hline [9] & - & Ibadan, South-west, (Urban) & 998 & $19-70$ & $40.0(8.3)$ & 17.4 & 8.7 \\
\hline
\end{tabular}




\section{Conclusion}

In conclusion, our findings emphasize the importance of implementing population-wide approaches to reduce diseases associated with increasing urbanization such as obesity in rapidly developing countries like China and Nigeria. Future studies on diet, physical activity and their determinants in urban populations are urgently needed. Specific urban public health policies to promote awareness especially among young adults, education, nutritional interventions, improved urban neighborhood planning and increased physical activity, should be integrated in national health policies to help control this epidemic in Africa.

\section{Competing interests}

The authors declare that they have no competing interests.

\section{Authors' contributions}

SA analyzed the data and drafted the manuscript. SA and CA conceived and designed the study. DS provided support for the data analysis and interpretation. CA, DS and WW provided critical reviews of the manuscript. All authors were involved in writing the paper and approval the submitted and final versions.

\section{Acknowledgements}

We thank the Global Nutrition Epidemiologic Transition Group, for their support.

The project described was supported by the Department of Nutrition, Harvard School of Public Health and Training Research Program (TRAPING-NCD) Grant Number D43TW009106, from the Fogarty International Centre.

\section{Author details}

'Department of Nutrition, Harvard School of Public Health, Boston, MA 02115, USA. ${ }^{2}$ Office of Strategic Information and Research, Institute of Human Virology, Abuja, Nigeria. ${ }^{3}$ Department of Epidemiology, Harvard School of Public Health, Boston, MA 02115, USA. ${ }^{4}$ Department of Biostatistics, Harvard School of Public Health, Boston, MA 02115, USA. Institute of Human Virology and Greenebaum Cancer Center, University of Maryland School of Medicine, Baltimore, MD 21201, USA.

Received: 4 September 2013 Accepted: 6 May 2014 Published: 15 May 2014

\section{References}

1. Lim SS, Vos T, Flaxman AD, Danaei G, Shibuya K, Adair-Rohani H, Amann M, Anderson HR, Andrews KG, Aryee M, Atkinson C, Bacchus LJ, Bahalim AN, Balakrishnan K, Balmes J, Barker-Collo S, Baxter A, Bell ML, Blore JD, Blyth F, Bonner C, Borges G, Bourne R, Boussinesq M, Brauer M, Brooks P, Bruce NG Brunekreef B, Bryan-Hancock C, Bucello C, et al: A comparative risk assessment of burden of disease and injury attributable to 67 risk factors and risk factor clusters in 21 regions, 1990-2010: a systematic analysis for the Global Burden of Disease Study 2010. Lancet 2013, 380:2224-2260.

2. WHO: Fact sheet on Obesity 2010; 2012. http://www.who.int/topics/obesity/en/.

3. Kelly T, Yang W, Chen CS, Reynolds K, He J: Global burden of obesity in 2005 and projections to 2030. Int J Obes 2008, 32:1431-1437.

4. Popkin BM, Adair LS, Ng SW: Global nutrition transition and the pandemic of obesity in developing countries. Nutr Rev 2012, 70:3-21.

5. Lozano R, Naghavi M, Foreman K, Lim S, Shibuya K, Aboyans V, Abraham J, Adair T, Aggarwal R, Ahn SY, Alvarado M, Anderson HR, Anderson LM, Andrews KG, Atkinson C, Baddour LM, Barker-Collo S, Bartels DH, Bell ML, Benjamin EJ, Bennett D, Bhalla K, Bikbov B, Bin Abdulhak A, Birbeck G, Blyth F, Bolliger I, Boufous S, Bucello C, Burch M, et al: Global and regional mortality from 235 causes of death for 20 age groups in 1990 and 2010: a systematic analysis for the Global Burden of Disease Study 2010. Lancet 2013, 380:2095-2128.

6. WHO: Obesity: preventing and managing the global epidemic. Report of a WHO consultation. World Health Organ Tech Rep Ser 2000, 894:1-253. i-xii.
7. Ono T, Guthold R, Strong K: WHO Global Comparable Estimates: Global Infobase data for saving lives 2005; 2012. https://apps.who.int/infobase/Index.aspx.

8. Martorell R, Khan LK, Hughes ML, Grummer-Strawn LM: Obesity in women from developing countries. Eur J Clin Nutr 2000, 54:247-252.

9. Olatunbosun ST, Kaufman JS, Bella AF: Prevalence of obesity and overweight in urban adult Nigerians. Obes Rev 2011, 12:233-241.

10. McLaren L: Socioeconomic status and obesity. Epidemiol Rev 2007, 29:29-48.

11. Abubakari AR, Lauder W, Agyemang C, Jones M, Kirk A, Bhopal RS: Prevalence and time trends in obesity among adult West African populations: a meta-analysis. Obes Rev 2008, 9:297-311.

12. Pasquet $P$, Temgoua LS, Melaman-Sego F, Froment A, Rikong-Adie H: Prevalence of overweight and obesity for urban adults in Cameroon. Ann Hum Biol 2003, 30:551-562.

13. WHO: Global Recommendations on Physical Activity for Health; 2010.

14. Molarius A, Kuulasmaa K, Sans S: Quality Assessment of Weight and Height Measurements in the WHO MONICA Project; 1998.

15. Akarolo-Anthony SN, Odubore FO, Yilme S, Aragbada O, Odonye G, Hu F, Willett W, Spiegelman D, Adebamowo CA: Pattern of dietary carbohydrate intake among urbanized adult Nigerians. Int J Food Sci Nutr 2013, 64:292-299.

16. Akarolo-Anthony SN, Adebamowo CA: Nigerian Food Composition Tables; 2013. Available from: http://www.globalhealthframework.net/global/

17. Filmer D, Pritchett LH: Estimating wealth effects without expenditure data-or tears: an application to educational enrollments in states of India. Demography 2001, 38:115-132.

18. Skinner S, Li R, Hertzmark E, Spiegelman D: The SAS RELRISK9 Macro; 2012. Available from: http://www.hsph.harvard.edu/donna-spiegelman/files/2012/ 08/relrisk9_Nov_2012.pdf.

19. Skov T, Deddens J, Petersen MR, Endahl L: Prevalence proportion ratios: estimation and hypothesis testing. Int J Epidemiol 1998, 27:91-95.

20. Zou G: A modified poisson regression approach to prospective studies with binary data. Am J Epidemiol 2004, 159:702-706.

21. Maldonado G, Greenland S: Simulation Study of Confounder-Selection Strategies. Am J Epidemiol 1993, 138:923-936.

22. Govindarajulu U, Spiegelman D, Thurston S, Eisen E: Comparing smoothing techniques for modeling exposure-response curves in Cox models. Stat Med 2007, 26:3735-3752.

23. Durrleman S, Simon R: Flexible regression models with cubic splines. Stat Med 1989, 8:551-561.

24. NPC: Nigeria Demographic and Health Survey; 2008

25. WHO: WHO Global Infobase Data for Saving Lives 2012; 2012. https://apps who.int/infobase/?id=1.

26. Oyeyemi AL, Adegoke BO, Oyeyemi AY, Deforche B, De Bourdeaudhuij I, Sallis JF: Environmental factors associated with overweight among adults in Nigeria. Int J Behav Nutr Phys Act 2012, 9:32.

27. Ejike $C E$, ljeh I: Obesity in young-adult Nigerians: variations in prevalence determined by anthropometry and bioelectrical impedance analysis, and the development of\% body fat prediction equations. Int Arch Med 2012, $5: 22$.

28. Akinpelu AO, Akinola OT, Gbiri CA: Adiposity and quality of life: a case study from an urban center in Nigeria. J Nutr Educ Behav 2009, 41:347-352.

29. Iloh G, Amadi AN, Nwankwo BO, Ugwu VC: Obesity in adult Nigerians: a study of its pattern and common primary co-morbidities in a rural Mission General Hospital in Imo state, South-Eastern Nigeria. Niger J Clin Pract 2011, 14:212-218.

30. Sola AO, Steven AO, Kayode JA, Olayinka AO: Underweight, overweight and obesity in adults Nigerians living in rural and urban communities of Benue State. Ann Afr Med 2011, 10:139-143.

31. Wahab KW, Sani MU, Yusuf BO, Gbadamosi M, Gbadamosi A, Yandutse MI: Prevalence and determinants of obesity - a cross-sectional study of an adult Northern Nigerian population. Int Arch Med 2011, 4:10.

32. Robinson WR, Gordon-Larsen P, Kaufman JS, Suchindran CM, Stevens J: The female-male disparity in obesity prevalence among black American young adults: contributions of sociodemographic characteristics of the childhood family. Am J Clin Nutr 2009, 89:1204-1212.

33. Holdsworth M, Gartner A, Landais E, Maire B, Delpeuch F: Perceptions of healthy and desirable body size in urban Senegalese women. Int $J$ Obes Relat Metab Disord 2004, 28:1561-1568.

34. Brink PJ: The fattening room in Nigeria. West J Nurs Res 1989, 11:655-656 
35. Brink PJ: The fattening room among the Annang of Nigeria. Med Anthropol 1989, 12:131-143.

36. Johansson L, Solvoll K, Bjorneboe GE, Drevon CA: Under- and overreporting of energy intake related to weight status and lifestyle in a nationwide sample. Am J Clin Nutr 1998, 68:266-274.

37. Mendez MA, Wynter S, Wilks R, Forrester T: Under- and overreporting of energy is related to obesity, lifestyle factors and food group intakes in Jamaican adults. Public Health Nutr 2004, 7:9-19.

38. Hu FB, Li TY, Colditz GA, Willett WC, Manson JE: Television watching and other sedentary behaviors in relation to risk of obesity and type 2 diabetes mellitus in women. JAMA 2003, 289:1785-1791.

39. The NHS, Information Centre LS: Statistics on obesity, physical activity and diet: England, 2012. ; 2012.

doi:10.1186/1471-2458-14-455

Cite this article as: Akarolo-Anthony et al:: Obesity epidemic has emerged among Nigerians. BMC Public Health 2014 14:455.

\section{Submit your next manuscript to BioMed Central and take full advantage of:}

- Convenient online submission

- Thorough peer review

- No space constraints or color figure charges

- Immediate publication on acceptance

- Inclusion in PubMed, CAS, Scopus and Google Scholar

- Research which is freely available for redistribution 